Research Article

\title{
Phenotypic and Molecular Characterization of $\beta$-Lactamases among Enterobacterial Uropathogens in Southeastern Nigeria
}

\author{
M. C. Ugwu $\mathbb{D}^{1,2}$ M. Shariff ${ }^{10},{ }^{2}$ C.M. Nnajide, ${ }^{1}$ K Beri, ${ }^{2}$ U. M. Okezie, ${ }^{1}$ I. R. Iroha, ${ }^{1,3}$ \\ and C. O. Esimone ${ }^{1}$ \\ ${ }^{1}$ Department of Pharmaceutical Microbiology \&Biotechnology, Nnamdi Azikiwe University Awka, Anambra, Nigeria \\ ${ }^{2}$ Department of Microbiology, Vallabhbhai Patel Chest Institute, University of Delhi, Delhi, India \\ ${ }^{3}$ Department of Applied Microbiology, Ebonyi State University, Abakiliki, Nigeria
}

Correspondence should be addressed to M. C. Ugwu; mc.ugwu@unizik.edu.ng

Received 28 July 2019; Revised 5 December 2019; Accepted 23 January 2020; Published 25 February 2020

Academic Editor: Maria Luisa Ricci

Copyright (C) 2020 M. C. Ugwu et al. This is an open access article distributed under the Creative Commons Attribution License, which permits unrestricted use, distribution, and reproduction in any medium, provided the original work is properly cited.

\begin{abstract}
Little is known about the molecular basis of antibiotic resistance among uropathogens in Southeast Nigeria. The aim of the study was to characterize enterobacterial uropathogens with respect to drug resistance. One hundred (100) enterobacterial uropathogens were studied. Their antibiotic susceptibility patterns were evaluated using disk diffusion, screened, and confirmed phenotypically for the presence of $\beta$-lactamases: ESBL, AmpC, carbapenemase, and MBLs. Screen positives were further tested for various $\beta$-lactamase genes by PCR. Our isolates showed variable resistance to most drugs tested. Out of the 58 ESBL screen positive E. coli, 35 were confirmed positive with PCR. The predominant ESBL gene was bla ${ }_{\mathrm{TEM}}$ while bla $\mathrm{SPM}_{\mathrm{SP}}$ was the most prevalent among MBL genes. Forty-six percentage of the screen positive Salmonella isolates coharbored bla $\mathrm{TEM}+\mathrm{SHV}$ genes. Nine of the $10 \mathrm{ESBL}$ screen positive K. pneumoniae were phenotypically and PCR positive. Three isolates of K. pneumoniae were positive for MBL genes. All the $10 \mathrm{C}$. freundii were positive for ESBL genes. The study showed high prevalence of drug-resistant genes among the enterobacterial uropathogens. Majority of the uropathogens harbored $>1$ antibiotic-resistant gene, and the most predominant gene was ESBL (bla $\mathrm{T}_{\mathrm{TEM}}$ ) followed by the MBL (SPM) gene.
\end{abstract}

\section{Introduction}

Urinary tract infections (UTIs) are among the commonest human bacterial infections occurring both in the community and hospital settings, particularly in developing countries with a high rate of casualty and financial cost $[1,2]$. UTI exist when the number of microorganisms $\left(\geq 10^{5}\right.$ cells per milliliter) of urine is detected in properly collected mid-stream clean catch urine [3]. UTIs are caused by a variety of pathogens but mostly by the Enterobacteriaceae $[1,4,5]$. Most of the uropathogenic bacteria are from the host bowel flora which enters the bladder through the urethra/bowel reservoir $[6,7]$. There have been increasing cases of antibiotic resistance among urinary tract pathogens. Though UTI is treatable, it is now becoming increasingly difficult to control because of antibiotic resistance, especially in the Enterobacteriaceae family [8]. As a result, these bacterial uropathogens are of public health concern with huge social and economic challenges $[1,8,9]$. The most common mechanism of resistance among the Enterobacteriaceae is the production of hydrolytic enzymes, the " $\beta$-lactamases" [10]. Complications in UTIs are on the increase because of the increasing prevalence of $\beta$-lactamases producing uropathogens [4]. Gram-negative bacteria that produce $\beta$-lactamases are a major concern in healthcare due to their ability to spread globally and the consequent limited treatment options due to the multiple resistance genes as well as the enzymes' associated link with resistance to other non-betalactam antibiotics [11-13]. Accurate identification of the antimicrobial resistance of a pathogen is decisive for 
improved diagnosis, judicious antibiotic use, infection control, and epidemiological surveillance [13].

Molecular genotyping has been used along with phenotyping techniques to screen and confirm expression of antimicrobial drug resistance within a population [11]. Till date, little is known about the molecular basis of antimicrobial resistance in bacteria isolated from UTI in Southeastern Nigeria as inadequate attention has been given to the understanding of the molecular epidemiology of uropathogens in Nigeria, a high-burden country. In appreciation of the above-outlined issues, this study was designed to investigate the antimicrobial susceptibilities, prevalence of $\beta$-lactamase phenotypes and genotypes among the enterobacterial uropathogens in Southeastern Nigeria.

\section{Materials Methods}

2.1. Isolation and Identification. Clean-catch urine samples were collected from patients (who had UTI as their primary diagnosis) attending Anambra State University Teaching Hospital, Amaku, Awka. The isolates were collected between June 2016 and Feb 2017. Verbal informed consent was obtained from all patients prior to specimen collection, and the study was conducted after obtaining due ethical approval from the Anambra State Ministry of Health (MH/COMM/ $523 / 68$ ) and the ethical committee of the hospital (COOUTH/AA/VOOL.1.002). No duplicate samples were collected. The bacterial isolates were identified with respect to their cultural and biochemical characteristics.

2.2. Antibiotic Susceptibility Study. Antibiotic susceptibility testing was done using Kirby-Bauer's disk diffusion method. The antibiotic disc (Himedia labs, India) containing the following antibiotics was used: cefoxitin $(30 \mu \mathrm{g})$, ceftazidime $(30 \mu \mathrm{g})$, cefotaxime $(30 \mu \mathrm{g})$, cefpodoxime $(30 \mu \mathrm{g})$, aztreonam $(30 \mu \mathrm{g})$, meropenem $(10 \mu \mathrm{g})$, ciprofloxacin $(30 \mu \mathrm{g})$, ofloxacin $(5 \mu \mathrm{g})$, norfloxacin $(10 \mu \mathrm{g})$, levofloxacin $(5 \mu \mathrm{g})$, cotrimoxazole $(25 \mu \mathrm{g})$, amoxicillin $(10 \mu \mathrm{g})$, and gentamicin $(10 \mu \mathrm{g})$. The inhibition zone diameters (IZDs) produced by the antibiotics were recorded and interpreted as per CLSI guidelines [14].

\subsection{Screening for ESBL, MBL, Carbapenemase, and AmpC} Production. The isolates were screened for ESBL production by checking their susceptibility against the $30 \mu \mathrm{g}$ disk each of ceftazidime, cefotaxime, cefpodoxime, and aztreonam. The screen positives were confirmed phenotypically by the modified combined disc on a Mueller-Hinton agar supplemented with $200 \mu \mathrm{g} / \mathrm{ml}$ cloxacillin. An isolate was considered an ESBL producer when the IZD around cefotaximeclavulanate and/or ceftazidime-clavulanate is $\geq 5$ compared with the IZD around the cefotaxime/ceftazidime disc $[15,16]$.

Meropenem-resistant isolates were further confirmed for MBL production by the meropenem (MRP)-EDTA combined disc test as described by Behera et al. [17]. An isolate was recorded to be $\mathrm{MBL}$ positive if there was a difference of $\geq 7 \mathrm{~mm}$ in IZD between the meropenem +EDTA disc and meropenem disc alone [17]. Similarly, the isolates were equally screened for carbapenemase production by checking their susceptibility to meropenem. An organism was considered to be carbapanamase screen positive if the IZD produced by meropenem is between $16-21 \mathrm{~mm}$. The screen positives were confirmed phenotypically using the modified Hodge test (MHT) according to a previously described method [18]. Briefly, standardized inoculums of E. coli ATCC 25922 were inoculated on a Mueller-Hinton agar plate. A $10 \mu \mathrm{g}$ meropenem disk (Himedia, India) was applied aseptically at the center of the inoculated Mueller-Hinton agar plate, and a suspension of the test isolate was streaked from the edge of the meropenem disk $(10 \mu \mathrm{g})$ to the edge of the Mueller-Hinton agar plate. After incubation at $37^{\circ} \mathrm{C}$ for 18-24 hrs, the Mueller-Hinton agar plates were observed for cloverleaf effect at the intersection of the test isolate and the $E$. coli ATCC 25922 organisms, within the inhibition zone of the meropenem disk $(10 \mu \mathrm{g})$. Isolates that were cefoxitin resistant were also screened for the presence of AmpC $\beta$-lactamase as previously described by Rynga et al. [19].

\subsection{Molecular Studies}

2.4.1. DNA Extraction. DNA extraction was carried out using HiPurATM Bacterial Genomic DNA purification Kit (HIMEDIA, category no MB505-50PR HiPurATM Bacterial Genomic DNA purification Kit) by following the manufacturer's instructions. The extracted DNA was stored at $-20^{\circ} \mathrm{C}$ and used for various molecular studies.

2.4.2. PCR Reactions. The isolates that were screen positive for ESBLs were subjected to multiplex PCR using specific primers for different families of ESBLs (Table 1):

2.4.3. PCR for ESBL (bla $a_{T E M}, b l a_{S H V}$, and bla $a_{\text {OXA-1-LIKE). }}$ ). Briefly, multiplex PCR reactions were performed in a final volume of $25 \mu \mathrm{l}$ of the amplification mixture containing 1.25 U of Taq DNA polymerase, $1 \mathrm{X}$ Taq buffer, $0.2 \mathrm{mM}$ each of dNTPs, $0.2 \mu \mathrm{M}$ of each primer, and $2 \mu \mathrm{l}$ of DNA template. The PCR was carried out with a Biorad thermal cycler (UK) using the following conditions: $94^{\circ} \mathrm{C}$ for $10 \mathrm{~min} ; 94^{\circ} \mathrm{C}$ for $30 \mathrm{sec}, 60^{\circ} \mathrm{C}$ for $40 \mathrm{sec}$, and $72^{\circ} \mathrm{C}$ for $1 \mathrm{~min}$ for $30 \mathrm{cycles}$, with a final extension at $72^{\circ} \mathrm{C}$ for $7 \mathrm{~min}$. PCR products were visualized on a $1.8 \%$ agarose gel stained with ethidium bromide.

2.4.4. PCR for ESBL (bla $a_{C T X-M 1}$, bla $a_{C T X-M 2}$, and bla $\left.{ }_{C T X-M 9}\right)$. Multiplex PCR reactions were performed in a final volume of $25 \mu \mathrm{l}$ of the amplification mixture containing $1.25 \mathrm{U}$ of Taq DNA polymerase, 1X Taq buffer, $0.2 \mathrm{mM}$ each of dNTPs, $0.2 \mu \mathrm{M}$ of each primer, and $2 \mu \mathrm{l}$ of DNA template. PCR was carried out with a Biorad thermal cycler (UK) using the following conditions: $94^{\circ} \mathrm{C}$ for $10 \mathrm{~min} ; 94^{\circ} \mathrm{C}$ for $40 \mathrm{sec}, 60^{\circ} \mathrm{C}$ for $40 \mathrm{sec}$, and $72^{\circ} \mathrm{C}$ for $1 \mathrm{~min}$ for 30 cycles, with a final extension at $72^{\circ} \mathrm{C}$ for $7 \mathrm{~min}$. PCR products were visualized on a $1.8 \%$ agarose gel stained with ethidium bromide. Similarly, the isolates were further screened for other ESBL 
TABLe 1: Primer sequence/PCR conditions for the ESBL resistance genotyping $[12,40]$.

\begin{tabular}{|c|c|c|c|c|}
\hline Genes & Primer sequences $\left(5^{\prime}-3^{\prime}\right)$ & Annealing temp. $\left({ }^{\circ} \mathrm{C}\right)$ & No. of cycles $(2-4)$ & Amplicon size (bp) \\
\hline TEM & $\begin{array}{l}\text { F: CATTTCCGTGTCGCCCTTATTC } \\
\text { R: CGTTCATCCATAGTTGCCTGAC }\end{array}$ & 60 & 30 & 800 \\
\hline SHV & $\begin{array}{l}\text { F: AGCCGCTTGAGCAAATTAAAC } \\
\text { R: ATCCCGCAGATAAATCACCAC }\end{array}$ & 60 & 30 & 713 \\
\hline OXA-1-like & $\begin{array}{l}\text { F: GGCACCAGATTCAACTTTCAAG } \\
\text { R: GACCCCAAGTTTCCTGTAAGTG }\end{array}$ & 60 & 30 & 564 \\
\hline CTX-M-1 & $\begin{array}{l}\text { F: TTAGGAAATGTGCCGCTGTA } \\
\text { R: CGATATCGTTGGTGGTACCAT }\end{array}$ & 60 & 30 & 688 \\
\hline CTX-M-2 & $\begin{array}{c}\text { F: CGTTAACGGCACGATGAC } \\
\text { R: CGATATCGTTGGTGGTACCAT }\end{array}$ & 60 & 30 & 404 \\
\hline CTX-M-9 & $\begin{array}{l}\text { F: TCAAGCCTGCCGATCTGGT } \\
\text { R: TGATTCTCGCCGCTGAAG }\end{array}$ & 60 & 30 & 561 \\
\hline GES $1-9,11$ & $\begin{array}{l}\text { F: AGTCGGCTAGACCGGAAAG } \\
\text { R: TTTGTCCGTGCTCAGGAT }\end{array}$ & 60 & 30 & 399 \\
\hline PER 1,3 & $\begin{array}{l}\text { F: GCTCCGATAATGAAAGCGT } \\
\text { R: TTCGGCTTGACTCGGCTGA }\end{array}$ & 60 & 30 & 520 \\
\hline VEB $1-6$ & $\begin{array}{l}\text { F: CATTTCCCGATGCAAAGCGT } \\
\text { R: CGAAGTTTCTTTGGACTCTG }\end{array}$ & 60 & 30 & 648 \\
\hline
\end{tabular}

genes: bla $\mathrm{VEB}_{\mathrm{V}}$, bla $\mathrm{G}_{\mathrm{GES}}$, and bla $\mathrm{PER}_{\mathrm{P}}$ using specific primers through multiplex PCR.

2.4.5. $P C R$ for $M B L, A m p C$, and KPC. The 25 isolates that were screen positive for MBLs by the phenotypic test were subjected to multiplex PCR using specific primers for different families of MBLs like bla $\mathrm{VIM}_{\mathrm{M}}$, bla $\mathrm{IMP}_{\mathrm{IMP}}$, bla $\mathrm{a}_{\mathrm{SPM}}$, bla $\mathrm{SII}_{\mathrm{SI}}$, and bla $_{\mathrm{GIM}}$ [19]. The multiplex reaction conditions were $94^{\circ} \mathrm{C}$ for $5 \mathrm{~min} ; 94^{\circ} \mathrm{C}$ for $30 \mathrm{sec}, 52^{\circ} \mathrm{C}$ for $40 \mathrm{sec}$, and $72^{\circ} \mathrm{C}$ for 50 secs for 36 cycles, with a final extension at $72^{\circ} \mathrm{C}$ for $5 \mathrm{~min}$. PCR products were visualized on a $1.8 \%$ agarose gel stained with ethidium bromide. PCR was equally carried out for AmpC (multiplex PCR) and KPC and NDM (uniplex PCR) using the primers and reaction conditions as in Table 2.

\section{Results}

A total of one hundred (100) enterobacterial uropathogens, E. coli (58), Salmonella (15), K. pneumoniae (14), Citrobacter freundii (10), and Enterobacter aerogenes (3), were isolated and identified from 300 urine specimens collected from patients that present with clinical symptoms of UTI and positive urine culture $\left(\geq 10^{5} \mathrm{CFU} / \mathrm{mL}\right)$.

The antibiotic susceptibility of the isolates shows that most of the E. coli isolates (Table 3) were resistant to cefpodoxime, cotrimoxazole, and meropenem, intermediately susceptible to aztreonam, cefotaxime, and ceftazidime but susceptible to the fluoroquinolones. Salmonella isolates, on the other hand (Table 4), had a very good susceptibility profile to the $3^{\text {rd }}$ generation cephalosporins (cefpodoxime, ceftriaxione, cefotaxime, and ceftazidime), intermediately susceptible to cefoxitin but were resistant to ofloxacin and cotrimoxazole. K. pneumoniae isolates were resistant to cefpodoxime, cefotaxime, and cotrimoxazole but susceptible to the fluoroquinolones (Table 5). Table 6 shows the summary of multiple antibiotic resistant indices (MARIs) of uropathogens. Only Salmonella spp and E. aerogenes had a MARI $<0.2$.
3.1. Phenotypic Screening of the Uropathogens for Beta-Lactamase Production. The screening tests showed $96 \%$ of the uropathogens (58 E. coli, 15 Salmonella, $10 \mathrm{~K}$. pneumoniae, $10 \mathrm{C}$. freundii, and $3 \mathrm{E}$. aerogenes) were screen positive for ESBL production while 58\% (21 E. coli, 15 Salmonella, $13 \mathrm{~K}$. pneumoniae, $6 \mathrm{C}$. freundii, and $3 \mathrm{E}$. aerogenes) were screen positive for AmpC.

3.2. Results of Molecular Studies. Out of the 58 ESBL screen positive E. coli, 35 (60.3\%) were confirmed positive with PCR (Table 7). The predominant gene was bla ${ }_{\mathrm{TEM}}$. Forty-two of the $E$. coli isolates were positive for various MBL genes by PCR. bla ${ }_{\mathrm{SPM}}$ was the most predominant MBL gene. Ten (10) of the $42 \mathrm{E}$. coli had coexpression of more than one MBL gene: [3( bla $_{\mathrm{IMP}}+$ bla $\left._{\mathrm{SPM}}\right), \quad \mathbf{1}\left(\mathrm{bla}_{\mathrm{SPM}}+\right.$ bla $\left._{\mathrm{GIM}}\right), \quad \mathbf{3}\left(\mathrm{bla}_{\mathrm{SPM}}+\mathrm{bla}_{\mathrm{SIM}}\right)$, $1\left(\right.$ bla $_{S P M}+$ bla $_{V I M}+$ bla $\left._{\text {SIM }}\right), 2\left(\right.$ bla $_{I M P}+b_{\text {la }}$ SPM + bla $_{\text {GIM }}+$ bla $\left.\left._{S I M}\right)\right]$. Two out of the $21 \mathrm{AmpC}$ screen positives were phenotypically positive for AmpC and only one of these was confirmed positive by PCR. Only $2 \mathrm{E}$. coli isolates were KPC positive by PCR while none of the $E$. coli isolates was positive for the NDM gene. Seven out of the 15 ESBL screen positive Salmonella isolates were confirmed by PCR to coharbor bla $\mathrm{TEM}_{\mathrm{TEM}}+$ bla $_{\mathrm{SHV}}$ genes, 3 isolates harboring $\operatorname{bla}_{\text {CTX-M2 }}(n=1), \operatorname{bla}_{\text {GES }}(n=1)$ and bla Of the $7 \mathrm{MBL}$ screen positive Salmonella, 2 were PCR confirmed positive: $1\left(\right.$ bla $\left._{\mathrm{IMP}}+\mathrm{bla}_{\mathrm{SPM}}+\mathrm{bla}_{\mathrm{VIM}}\right)$ and 1 $\left(b a_{I M P}+b a_{V I M}+b_{\text {GIM }}\right)$. Nine of the 10 ESBL screen positive $K$. pneumoniae were phenotypically and PCR positive, 5 of which had coexpression of bla $\mathrm{TEM}_{\mathrm{T}}$, bla $\mathrm{S}_{\mathrm{SHV}}$,

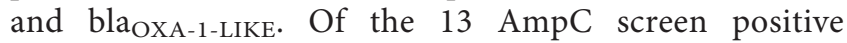
$K$. pneumoniae, none was confirmed to be a AmpC producer. Three isolates of $K$. pneumoniae were positive for MBL genes: $\operatorname{bla}_{\mathrm{IMP}}(n=1)$, bla $_{\mathrm{IMP}}+$ bla $_{\mathrm{VIM}}+$ bla $_{\mathrm{GIM}}(n=1)$, and bla $_{\mathrm{IMP}}+\mathrm{bla}_{\mathrm{GIM}}+$ bla $_{\mathrm{VIM}}+$ bla $_{\mathrm{SIM}}(n=1)$. All the $10 \mathrm{C}$. freundii were positive for ESBL genes. Bla ${ }_{\text {TEM }}$ was the predominant ESBL gene. It existed in combination with bla $_{\mathrm{GES}}$ in 5 isolates and with bla $\mathrm{VEB}_{\mathrm{V}}$ in 1 isolate. Two out of the 21 AmpC screen positives were phenotypically positive 
TABle 2: Primer sequence/PCR conditions for the MBL, AmpC, KPC, and NDM resistance genotyping [41-42].

\begin{tabular}{|c|c|c|c|c|}
\hline Genes & Primer sequences $\left(5^{\prime}-3^{\prime}\right)$ & Annealing temperature $\left({ }^{\circ} \mathrm{C}\right)$ & No. of cycles (2-4) & Amplicon size (bp) \\
\hline VIM & $\begin{array}{l}\text { F: GAT GGT GTT TGG TCG CAT } \\
\text { R: CGA ATG CGC AGC ACC AGA }\end{array}$ & 52 & 36 & 390 \\
\hline IMP & $\begin{array}{l}\text { F: GGA ATA GAG TGG CTT AAT CTC } \\
\text { R: CCA AAC YAC TAS GTT ATC T }\end{array}$ & 52 & 36 & 180 \\
\hline GIM & $\begin{array}{l}\text { F: TCG ACA CAC CTT GGT CTG AA } \\
\text { R: AAC TTC CAA CTT TGC CAT GC }\end{array}$ & 52 & 36 & 477 \\
\hline SPM & $\begin{array}{l}\text { F: AAA ATC TGG GTA CGC AAA CG } \\
\text { R: ACA TTA TCC GCT GGA ACA GG }\end{array}$ & 52 & 36 & 271 \\
\hline SIM & $\begin{array}{l}\text { F: TAC AAG GGA TTC GGC ATC G } \\
\text { R: TAA TGG CCT GTT CCC ATG TG }\end{array}$ & 52 & 36 & 570 \\
\hline MOXM & $\begin{array}{l}\text { F: GCT GCT CAA GGA GCA CAG GAT } \\
\text { R: CAC ATT GAC ATA GGT GTG GTG C }\end{array}$ & 64 & 25 & 520 \\
\hline CITM & $\begin{array}{l}\text { F: TGG CCA GAA CTG ACA GGC AAA } \\
\text { R: TTT CTC CTG AAC GTG GCT GGC }\end{array}$ & 64 & 25 & 462 \\
\hline DHAM & $\begin{array}{l}\text { F: AAC TTT CAC AGG TGT GCT GGG T } \\
\text { R: CCG TAC GCA TAC TGG CTT TGC }\end{array}$ & 64 & 25 & 405 \\
\hline ACCM & $\begin{array}{l}\text { F: AAC AGC CTC AGC AGC CGG TTA } \\
\text { R: TTC GCC GCA ATC ATC CCT AGC }\end{array}$ & 64 & 25 & 346 \\
\hline EBCM & $\begin{array}{l}\text { F: TCG GTA AAG CCG ATG TTG CGG } \\
\text { R: CTT CCA CTG CGG CTG CCA GTT }\end{array}$ & 64 & 25 & 302 \\
\hline FOXM & $\begin{array}{l}\text { F: AAC ATG GGG TAT CAG GGA GAT G } \\
\text { R: CAA AGC GCG TAA CCG GAT TGG }\end{array}$ & 64 & 25 & 190 \\
\hline NDM-1 & $\begin{array}{l}\text { F: ACC GCC TGG ACC GAT GAC CA } \\
\text { R: GCC AAA GTT GGG CGC GGT TG }\end{array}$ & 58 & 35 & 264 \\
\hline KPC & $\begin{array}{l}\text { F: CATTCAAGGGCTTTCTTGCTGC } \\
\text { R: ACGACGGCATAGTCATTTGC }\end{array}$ & 55 & 30 & 538 \\
\hline
\end{tabular}

TABle 3: Antibiotic susceptibility pattern of E. coli $(n=58)$.

\begin{tabular}{|c|c|c|c|c|}
\hline \multirow{2}{*}{ S/no } & \multirow{2}{*}{ Antibiotics } & \multicolumn{3}{|c|}{ No. of isolates (\%) } \\
\hline & & Resistant & Intermediate & Susceptible $n$ \\
\hline 1 & Cefpodoxime (CPD) & $35(60.34)$ & $19(32.76)$ & $4(6.90)$ \\
\hline 2 & Ceftriaxone (CTR) & $0(0)$ & $10(17.24)$ & $48(82.76)$ \\
\hline 3 & Aztreonam (AT) & $1(1.72)$ & $36(62.07)$ & $21(36.21)$ \\
\hline 4 & Cefotaxime (CTX) & $8(13.79)$ & $33(56.90)$ & $17(29.31)$ \\
\hline 5 & Ceftazidime (CAZ) & $1(1.72)$ & $34(58.62)$ & $23(39.66)$ \\
\hline 6 & Meropenem (MRP) & $9(15.52)$ & $7(12.06)$ & $42(72.41)$ \\
\hline 7 & Cefoxitin (CX) & $3(5.17)$ & $11(18.97)$ & $44(75.86)$ \\
\hline 8 & Ofloxacin (OF) & $4(6.90)$ & $4(6.90)$ & $50(86.21)$ \\
\hline 9 & Ciprofloxacin (CIP) & $4(6.90)$ & $10(17.24)$ & $44(75.86)$ \\
\hline 10 & Norfloxacin (NX) & $5(8.62)$ & $1(1.72)$ & $51(87.93)$ \\
\hline 11 & Levofloxacin (LE) & $4(6.90)$ & $0(0)$ & $54(93.10)$ \\
\hline 12 & Cotrimoxazole (COT) & $29(50)$ & $1(1.72)$ & $26(44.83)$ \\
\hline 13 & Gentamicin (GEN) & $6(10.34)$ & $6(10.34)$ & $45(77.59)$ \\
\hline 14 & Amoxicillin (AMX) & $16(27.59)$ & $3(5.17)$ & $20(34.48)$ \\
\hline
\end{tabular}

for AmpC, and only one of these was confirmed positive by PCR. Only 2 E. coli isolates were KPC positive by PCR.

\section{Discussion}

Enterobacteriaceae are the highest reported causes of UTI and are usually resistant to several antibiotics resulting in recurrent UTIs, especially in the high-risk population $[16,20,21]$.

They present a public health challenge and thus deserve an adequate attention. For an in-depth understanding of the underlying resistance genotypes and/mechanisms, this study characterized the enterobacterial uropathogens with respect to drug resistance and their $\beta$-lactamase production capacities. Antibiotic resistance is a key clinical and public health challenge in treating UTI. Emergence of $\beta$-lactamase producers among the Enterobacteriaceae reduces therapeutic options because the isolates often coexpress resistance to other classes of antibiotics. Our predominant isolates ( $E$. coli, Salmonella spp., and K. pneumoniae) showed variable resistance to most antibiotics tested. This is similar to the findings of Ekwealor et al. [1]. The fluoroquinolones and gentamicin were highly active against $E$. coli isolates and thus can be prescribed for the empiric treatment of UTI caused by 
TABLe 4: Antibiotic susceptibility pattern of Salmonella spp. $(n=15)$.

\begin{tabular}{|c|c|c|c|c|}
\hline \multirow{2}{*}{ S/no } & \multirow{2}{*}{ Antibiotics } & \multicolumn{3}{|c|}{ No. of isolates (\%) } \\
\hline & & Resistant & Intermediate & Susceptible \\
\hline 1 & Cefpodoxime (CPD) & $0(0)$ & $0(0)$ & $15(100)$ \\
\hline 2 & Ceftriaxione (CTR) & $2(13.33)$ & $0(0)$ & $13(86.67)$ \\
\hline 3 & Aztreonam (AT) & $0(0)$ & $2(13.33)$ & $13(86.67)$ \\
\hline 4 & Cefotaxime (CTX) & $2(13.33)$ & $0(0)$ & $13(86.67)$ \\
\hline 5 & Ceftazidime (CAZ) & $1(6.67)$ & $4(26.67)$ & $10(66.67)$ \\
\hline 6 & Meropenem (MRP) & $8(53.33)$ & $1(6.67)$ & $6(40)$ \\
\hline 7 & Cefoxitin (CX) & $0(0)$ & $14(93.33)$ & $1(6.67)$ \\
\hline 8 & Ofloxacin (OF) & $11(73.33)$ & $4(26.67)$ & $0(0)$ \\
\hline 9 & Ciprofloxacin (CIP) & $8(53.33)$ & $6(40)$ & $1(6.67)$ \\
\hline 10 & Norfloxacin (NX) & $8(53.33)$ & $3(20)$ & $4(26.67)$ \\
\hline 11 & Levofloxacin (LE) & $9(60)$ & $2(13.33)$ & $4(26.67)$ \\
\hline 12 & Cotrimoxazole (COT) & $10(66.67)$ & $0(0)$ & $4(26.67)$ \\
\hline 13 & Gentamicin (GEN) & $7(46.67)$ & $0(0)$ & $8(53.33)$ \\
\hline
\end{tabular}

TABle 5: Antibiotic susceptibility pattern of $K$. pneumoniae $(n=14)$.

\begin{tabular}{|c|c|c|c|c|}
\hline \multirow{2}{*}{ S/no } & \multirow{2}{*}{ Antibiotics } & \multicolumn{3}{|c|}{ No. of isolates (\%) } \\
\hline & & Resistant & Intermediate & Susceptible \\
\hline 1 & Cefpodoxime (CPD) & $10(71.43)$ & $0(0)$ & $0(0)$ \\
\hline 2 & Ceftriaxione (CTR) & $4(28.57)$ & $4(28.57)$ & $2(14.29)$ \\
\hline 3 & Aztreonam (AT) & $7(50)$ & $2(14.29)$ & $1(7.14)$ \\
\hline 4 & Cefotaxime (CTX) & $9(64.29)$ & $0(0)$ & $1(7.14)$ \\
\hline 5 & Ceftazidime (CAZ) & $6(42.86)$ & $3(21.43)$ & $1(7.14)$ \\
\hline 6 & Meropenem (MRP) & $4(28.57)$ & $3(21.43)$ & $3(21.43)$ \\
\hline 7 & Cefoxitin (CX) & $7(50)$ & $3(21.43)$ & $0(0)$ \\
\hline 8 & Ofloxacin (OF) & $5(35.71)$ & $0(0)$ & $9(64.29)$ \\
\hline 9 & Ciprofloxacin (CIP) & $5(35.71)$ & $2(14.29)$ & $7(50)$ \\
\hline 10 & Norfloxacin (NX) & $5(35.71)$ & $0(0)$ & $9(64.29)$ \\
\hline 11 & Levofloxacin (LE) & $5(35.71)$ & $0(0)$ & $9(64.29)$ \\
\hline 12 & Cotrimoxazole (COT) & $8(57.14)$ & $0(0)$ & $6(42.86)$ \\
\hline 13 & Gentamicin (GEN) & $4(28.57)$ & $4(28.57)$ & $5(35.71)$ \\
\hline 14 & Amoxicillin (AMX) & $10(71.43)$ & $0(0)$ & $0(0)$ \\
\hline
\end{tabular}

TABLE 6: Summary of multiple antibiotic-resistant indices (MARIs) of uropathogens.

\begin{tabular}{lcc}
\hline Isolates & \multicolumn{2}{c}{ Number of isolates $(\%)$} \\
& MARI $>0.2$ & MARI $\leq 0.2$ \\
\hline Klebsiella spp & $14(100)$ & $0(0)$ \\
E. coli & $33(57)$ & $25(43)$ \\
Salmonella spp & $13(87)$ & $2(13)$ \\
Citrobacter spp & $7(70)$ & $3(30)$ \\
Enterobacter spp & $2(67)$ & $1(33)$ \\
Total & $69(69)$ & $31(31)$ \\
\hline
\end{tabular}

Total number of antibiotics tested $=14$.

E. coli. Similarly, in Libya, Abubaker et al. [5] reported a very good susceptibility of uropathogenic E. coli to ciprofloxacin, and a very low resistance to gentamicin was equally reported by Elsayed et al. [4] in Egypt.

Unlike the E. coli isolates, the salmonella spp. was resistant to the fluoroquinolones. The susceptibility test for K. pneumoniae showed that amoxicillin, cefpodoxime, cefotaxime, aztreonam, and cefoxitin exhibited very poor antipneumococcal activity while the fluoroquinolones showed very good activity and is in agreement with the reports of Sikarwar \& Batra [22] that a fluoroquinolone, ciprofloxacin, had a $90 \%$ antibacterial activity against uropathogens. It was observed that $K$. pneumoniae isolates (Table 5) were more resistant to most of the antimicrobial agents tested than E. coli and Salmonella isolates. A similar scenario of multidrug resistance (MDR) of uropathogenic Klebsiella spp. has been reported in Libya [5]. It should be noted that all the isolates had poor susceptibility to cotrimoxazole and amoxicillin. This is in agreement with what was reported in Ethiopia where a high level of resistance $(>70 \%)$ was recorded for cotrimoxazole and ampicillin by uropathogens [23]. The observed low susceptibility might be connected with the misuse of the agents as cotrimoxazole and ampicillin were the first choice of drugs for the empirical treatment of UTI [23]. Several researches have reported increasing prevalence of trimethoprim-sulfamethoxazole-resistant uropathogenic strains and suggested fluoroquinolones as an alternative treatment choice for UTI [24]. E. coli and Salmonella were very sensitive to aztreonam and ceftazidime. This observed low resistance rates may be due to 
TABLE 7: Summary of bla-PCR-positive isolates.

\begin{tabular}{|c|c|c|c|c|c|c|c|c|}
\hline Organisms & TEM & SHV & OXA-1-like & $\mathrm{TEM}+\mathrm{SHV}$ & TEM + OXA-I-LIKE & TEM + SHV + OXA-1-LIKE & MBL & AmpC \\
\hline E. $\operatorname{coli}(58)$ & 31 & 1 & 0 & 3 & 0 & 0 & 10 & 1 \\
\hline C. freundii (10) & 10 & 0 & 0 & 0 & 0 & 0 & 0 & 1 \\
\hline K. pneuminiae (14) & 2 & 2 & 0 & 0 & 2 & 3 & 3 & 0 \\
\hline Salmonella spp (15) & 0 & 0 & 0 & 7 & 0 & 0 & 2 & 0 \\
\hline Total & 43 & 3 & 0 & 10 & 2 & 3 & 15 & 2 \\
\hline
\end{tabular}

Table 8: Antibiotic susceptibility pattern of Citrobacter freundii $(n=10)$.

\begin{tabular}{lcccc}
\hline \multirow{2}{*}{ S/no } & \multirow{2}{*}{ Antibiotics } & \multicolumn{3}{c}{ No. of isolates (\%) } \\
& & Resistant & Intermediate & Susceptible \\
\hline 1 & Cefpodoxime (CPD) & $8(80)$ & $2(20)$ & $0(0)$ \\
2 & Ceftriaxione (CTR) & $4(40)$ & $4(40)$ & $2(20)$ \\
3 & Aztreonam (AT) & $3(30)$ & $6(60)$ & $1(10)$ \\
4 & Cefotaxime (CTX) & $6(60)$ & $2(20)$ & $2(20)$ \\
5 & Ceftazidime (CAZ) & $2(20)$ & $6(60)$ & $2(20)$ \\
6 & Meropenem (MRP) & $1(10)$ & $3(30)$ & $6(60)$ \\
7 & Cefoxitin (CX) & $5(50)$ & $0(0)$ & $5(50)$ \\
8 & Ofloxacin (OF) & $0(0)$ & $3(30)$ & $6(60)$ \\
9 & Ciprofloxacin (CIP) & $0(0)$ & $5(50)$ & $5(50)$ \\
10 & Norfloxacin (NX) & $1(10)$ & $2(20)$ & $8(80)$ \\
11 & Levofloxacin (LE) & $0(0)$ & $1(10)$ & $9(90)$ \\
12 & Cotrimoxazole & $7(70)$ & $0(0)$ & $3(30)$ \\
13 & Gentamicin (GEN) & $1(10)$ & $0(0)$ & $9(90)$ \\
14 & Amoxicillin (AMX) & $8(80)$ & $0(0)$ & $2(20)$ \\
\hline
\end{tabular}

less use of these drugs in treating bacterial infections in Nigeria. A significant sensitivity to gentamicin was noted with E. coli and C. freundii (Tables $3 \& 8$ ). Two related studies in Abakilikii and Enugu both in Southeastern Nigeria equally reported a remarkable susceptibility of uropathogens to gentamicin $[18,25]$. This might be because gentamicin being a parenteral preparation might be used with much restriction. Improper antibiotic use, dose, and duration of administration have been reported as predisposing factors for the emergence of antibiotic-resistant strains in a locality [4]. Commonly, in our hospitals ceftriaxione is used empirically for inpatients and amoxicillin-clavulanate for outpatients by the physicians. The choice of drug treatments will further be determined by the sensitivity tests.

Sixteen $(27.6 \%)$ of the screen positive E. coli were phenotypically confirmed to be ESBL producers (Table 9). Similar rates $(27.7 \%)$ of ESBLs have been reported from a neighboring southeastern state, Enugu, by Ejikeugwu et al. [18] and $26.1 \%$ in southwestern Nigeria [26]. Lower prevalence $(6.7 \%)$ of ESBLs was detected phenotypically among uropathogenic E. coli in northwestern Libya [5]. However, higher prevalence of ESBL-producing uropathogenic E. coli (38.9\%) was reported in Nepal [11], 40\% in Potohar region of Pakistan by Ali et al. [24], and 83\% in Doha, Qatar [20]. The rates of resistance of ESBL-producing bacteria to antibiotics have previously been reported to be geographically dependent. This is due to the differences in antimicrobial usages and infection control measures in these locations [27].
On the molecular level, the prevalence of ESBL production was E. coli (60.34\%), C. freundii (100\%), K. pneumoniae (64.28\%), and Salmonella spp. (46.66\%). These high rates are of serious issue as the spread of these enzymes is normally driven by mobile genetic elements which facilitate the horizontal transmission of the resistance genes among bacteria of other species [28]. In addition, they often carry genes that encode high levels of resistance to many other antibiotics and cause high therapeutic failures among infected patients $[16,29]$. The increasing prevalence of infections caused by antibiotic-resistant bacteria makes the empirical treatment of UTI difficult and the outcome unpredictable. It is thus associated with higher cost of therapy, increased risk of complications, morbidity, and mortality $[4,16]$. Many studies reported that urine of UTI patients harbors ESBL-producing E. coli $[5,30]$. A similar observation was noted by Iroha et al. [31] in the neighboring Enugu state where $81.8 \%$ of ESBL-producing strains of E. coli was isolated from urine of outpatients in a tertiary care hospital. ESBLs have been reported among 51-90\% of Enterobacteriaceae in Asia. Similar to our findings, Padmavathy et al. [32] reported that the percentage of ESBL-producing E. coli was $66.9 \%$ in Chennai, India.

The high levels of ESBL producers are a major threat to infection management as this may have contributed to the antibiotic resistance reported in this study. ESBL-producing organisms are known to contain plasmids with genes that encode resistance to quinolones, aminoglycosides, and cotrimoxazole. This is exemplified in the resistance profile of K. pneumoniae (Table 5). The high prevalence of bla $\mathrm{T}_{\mathrm{TEM}}$ among the $C$. freundii isolates (Table 8 ) might be responsible for their high resistance to the $\beta$-lactams amoxicillin (80\%), cefpodoxime $(80 \%)$, and ceftazidime $(60 \%)$ ) as observed in Table 6. It has been reported previously that resistance to oxyimino-cephalosporins (e.g., cefpodoxime and ceftazidime), is caused mostly by TEM-type of ESBL [14]. However, ESBL-producing E. coli and C. freundii isolates were susceptible to fluoroquinolones. This finding is in line with a similar study done in Southeastern Nigeria by Iroha et al. [33]. They advised limited use of any cephalosporin on an ESBL positive E. coli infection. Since E. coli isolates showed high prevalence of resistance to various antibiotics, strategies to control the increase in resistant uropathogens would be important. The observed low resistance of E. coli (13.8\%) and Salmonella spp (13.3\%) to cefotaxime and high susceptibility to ceftriaxone (>80\%) might be due to the low prevalence of

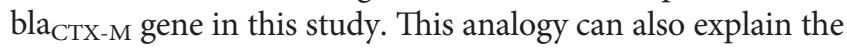
high resistance profile of $K$. pneumoniae (64.9\%) to cefotaxime as 5 of the $14 \mathrm{~K}$. pneumoniae isolates harboured the

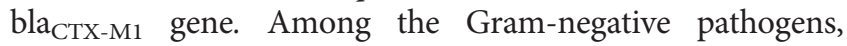


TABLE 9: Differences between bla-phenotypic and bla-PCR positives.

\begin{tabular}{|c|c|c|c|c|c|c|}
\hline \multirow{2}{*}{ Organisms } & \multicolumn{2}{|l|}{ ESBL } & \multicolumn{2}{|l|}{ MBL } & \multicolumn{2}{|c|}{ AmpC } \\
\hline & Phenotypic positive & PCR-positive & Phenotypic positive & PCR-positive & Phenotypic positive & PCR-positive \\
\hline E. coli $(58)$ & 16 & 35 & 3 & 10 & 2 & 1 \\
\hline C. freundii (10) & 5 & 10 & 0 & 0 & 0 & 1 \\
\hline K. pneuminiae (14) & 9 & 9 & 0 & 3 & 0 & 0 \\
\hline Salmonella spp (15) & 1 & 7 & 0 & 2 & 2 & 0 \\
\hline Total & 31 & 61 & 3 & 15 & 4 & 2 \\
\hline
\end{tabular}

bla $_{\text {CTX-M }}$ genes have been reported as a vital mechanism of resistance to cefotaxime and ceftriaxone [8]. Our findings are in line with the reports of Eskandari-Nasab et al. [34] in which

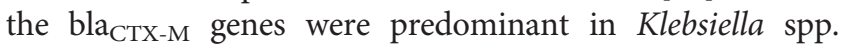
Similarly Kuldeep and Nitika [21] stated that majority of ESBLs in E. coli are derived from the common plasmid

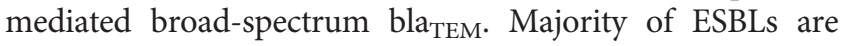
derived from plasmid mediated penicillinases of the TEM and SHV families [35]. Low levels of bla $\mathrm{GES}_{\mathrm{G}}$, bla $\mathrm{VEB}_{\mathrm{VEB}}$, and bla $\mathrm{a}_{\mathrm{PER}}$ were reported in this study. It has been stated that the most frequently detected clinically important ESBLs belong to the TEM, SHV, and CTX-M families while GES, VEB, and PER are of less prevalence $[28,36]$. Although, the frequency of ESBL-producing isolates is increasing, the rate of infection can be minimized by regular surveillance and monitoring in order to institute effective and credible treatment of UTI.

MBLs have been recognized as one of the most notable resistance determinants in Enterobacteriaceae [37]. The SPM gene was the most predominant MBL gene in our study. There was mixed expression of the MBL genes among our isolates. Ten (10) of the $25 \mathrm{MBL}$ screen positive E. coli had coexpression of more than one MBL gene. There are increasing reports of MBL-producing Gram-negative bacteria in southeastern Nigeria. Ejikeugwu et al. [38] had reported high occurrence of MBL-producing E. coli and Klebsiella species from an abattoir. Since the genes that code for MBL production in Gram negatives are chromosomally or plasmid mediated, they can easily be transmitted through mobile genetic elements among bacterial population in a community [39]. The discrepancy in the percentage of phenotypic and genotypic $\beta$-lactamase confirmed producers (Table 9) might be because of coexpression of more than one ESBL, $\mathrm{MBL}$, and/or AmpC genes in an organism. Occurrence of multiple ESBL types and/or ESBL-AmpC combinations within the same organism has previously been reported to make phenotypic identification of the $\beta$-lactamases difficult and not reliable [32]. It might also be that the genes detected by PCR are not effectively expressed phenotypically [40]. Similarly, Krishnamurthy et al. [35] observed a significant difference in detection of ESBL positive isolates by phenotypic and genotypic methods. They attributed it to lower sensitivity of the phenotypic method and the influence of environmental factors and maintained that the genotypic method has a $100 \%$ specificity and sensitivity as it uses specific PCR amplification of resistance genes.

We confirmed low prevalence of AmpC and KPC genes among our uropathogens while none of the $E$. coli isolates was positive for NDM genes. The AmpC producer was also found to be ESBLs negative. The low prevalence of AmpC genes in our study is likely to be responsible for the observed high susceptibility of E. coli (75\%) and intermediately susceptible of Salmonella to cefoxitin. Conversely, a study in Chennai, India, reported that $61.9 \%$ of the uropathogenic $E$. coli isolates expressed an AmpC phenotype [32].

\section{Conclusion}

The uropathogens were found to be resistant to various antimicrobial classes studied. The study showed high prevalence of drug-resistant genes among the enterobacterial uropathogens. Majority of the enterobacterial uropathogens harbored more than one antibiotic-resistant gene. Our study has notably shown that of all the ESBL genes, the most predominant gene in E. coli and C. freundii was bla ${ }_{\mathrm{TEM}}$, in Salmonella spp was a combination of bla $\mathrm{TEM}_{+} \mathrm{SHV}$, and in

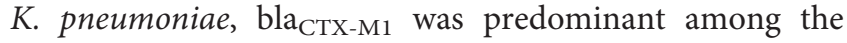
enterobacterial uropathogens isolated from patients of Anambra State University Teaching Hospital, Awka. The genotypic method has a higher specificity/sensitivity than the phenotypic method as thus should be a method of choice for detection of ESBL-producing strains. Limitations of the study are that we didn't record the patient's demographics and history of their antibiotic consumption. We also could not screen specifically for OXA-48 genes.

\section{Data Availability}

The data used to support the findings of this study are included within the article.

\section{Ethical Approval}

The study was ethically approved by the Anambra State Ministry of Health (MH/COMM/523/68) and the ethical committee of the hospital (COOUTH/AA/VOOL.1.002) while informed consent was taken from the patients.

\section{Conflicts of Interest}

The authors declare that there are no conflicts of interest regarding the publication of this paper.

\section{Acknowledgments}

This study was funded by NAM S\&T Centre, India, under Research Training Fellowship for Developing Country Scientists (RTF-DCS, 2016-17) awarded to MC Ugwu (NAM-05/74/2016) and supported by Vallabhbhai Patel Chest Institute, India. This work was carried out at the 
Department of Microbiology, Vallabhbhai Patel Chest Institute, University of Delhi, India; the authors therefore acknowledge support received from the members of staff of Patel Chest Institute, India.

\section{References}

[1] P. A. Ekwealor, M. C. Ugwu, I. Ezeobi et al., “Antimicrobial evaluation of bacterial isolates from urine specimen of patients with complaints of urinary tract infections in Awka, Nigeria," International Journal of Microbiology, vol. 2016, Article ID 9740273, 6 pages, 2016.

[2] B. Oladeinde, R. Omoregie, M. Olley, and J. Anunibe, "Urinary tract infection in a rural community of Nigeria," North American Journal of Medical Sciences, vol. 3, no. 2, pp. 75-77, 2011.

[3] K. Iregbu and P. Nwajiobi-Princewill, "Urinary tract infections in a tertiary hospital in Abuja, Nigeria," African Journal of Clinical and Experimental Microbiology, vol. 14, no. 3, pp. 169-173, 2013.

[4] T. I. Elsayed, H. A. Ismail, S. A. Elgamal et al., "The occurrence of multidrug resistant E. Coli which produce ESBL and cause urinary tract infections," Journal of Applied Microbiology and Biochemistry, vol. 1, no. 1, pp. 2-8, 2017.

[5] A. A. Abubaker, Z. Abdulaziz, A. M. Mohamed, H. A. Sabri, A. K. Rania, and S. G. Khalifa, "Multidrug resistance and extended-spectrum b-lactamases genes among Escherichia coli from patients with urinary tract infections in northwestern Libya," Libyan Journal of Medicine, vol. 10, no. 1, Article ID 26412, 2015.

[6] S. Altarac, "Urinary tract infection: how it happens?" European Journal of Medicine, vol. 3, no. 1, pp. 62-67, 2015.

[7] J. Bien, O. Sokolova, and P. Bozko, "Role of uropathogenic Escherichia coli virulence factors in development of urinary tract infection and kidney damage," International Journal of Nephrology, vol. 2012, Article ID 681473, 15 pages, 2012.

[8] A Hussain, C Ewers, N Nandanwar, S Guenther, S. Jadhav, and L. H. Wieler, "Multiresistant uropathogenic Escherichia coli from a region in India where urinary tract infections are endemic: genotypic and phenotypic characteristics of sequence type 131 isolates of the CTXM-15 extended-spectrum$\beta$-Lactamase-producing Lineage," Antimicrobial Agents and Chemotherapy, vol. 56, no. 12, pp. 6358-6365, 2012.

[9] D. Prakash and R. S. Saxena, "Distribution and antimicrobial susceptibility pattern of bacterial pathogens causing urinary tract infection in Urban Community of Meerut City, India," ISRN Microbiology, vol. 2013, Article ID 749629, 13 pages, 2013.

[10] N. Parajul, P. M. Prasad, P. Hridaya et al., "High rates of multidrug resistance among uropathogenic Escherichia coli in children and analyses of ESBL producers from Nepal," Antimicrobial Resistance \& Infection Control, vol. 6, no. 9, pp. 1-7, 2017.

[11] E. J. Alyamani, A. M. Khiyami, R. Y. Booq, A. Majrashi, F. S. Bahwerth, and E. Rechkina, "The occurrence of ESBLproducing Escherichia coli carrying aminoglycoside resistance genes in urinary tract infections in Saudi Arabia," Annals of Clinical Microbiology and Antimicrobials, vol. 16, no. 1, pp. 1-13, 2017.

[12] C. A. Enwuru, B. Iwalokun, N. V. Enwuru, O. Ezechi, N. Idika, and A. Oluwadun, "The occurrence and modified method for phenotypic identification of ambler group A and B extended spectrum $\beta$-lactamases production in urino-genital gram negative bacterial isolates from, Nigeria," Nature and Science, vol. 11, no. 8, pp. 1-6, 2013.

[13] D. M. Leinberger, V. Grimm, M. Rubtsova et al., "Integrated detection of extended-spectrum-beta-lactam resistance by DNA microarray-based genotyping of TEM, SHV, and CTXM genes," Journal of Clinical Microbiology, vol. 48, no. 2, pp. 460-471, 2010.

[14] Clinical and Laboratory Standards Institute, Performance Standards for Antimicrobial Susceptibility Testing; Eighteenth Informational Supplement M100-S27, Clinical and Laboratory Standards Institute, Wayne, PA, USA, 2017.

[15] K. S. Thomson, "Extended-spectrum-lactamase, AmpC, and carbapenemase issues," Journal of Clinical Microbiology, vol. 48, no. 4, pp. 1019-1025, 2010.

[16] P. C. Ejikeugwu, C. M. Ugwu, C. O. Araka et al., "Imipenem and meropenem resistance amongst ESBL producing Escherichia coli and Klebsiella pneumonia clinical isolates," International Journal of Microbiology, vol. 3, no. 10, pp. 339-344, 2012.

[17] B. Behera, P. Mathur, A. Das, A. Kapil, and V. Sharma, “An evaluation of four different phenotypic techniques for detection of metallo-B-lactamase producing Pseudomonas aeruginosa," Indian Journal of Medical Microbiology, vol. 26, no. 3, pp. 233-237, 2008.

[18] C. Ejikeugwu, M. Ugwu, I. Iroha et al., "Detection and antimicrobial susceptibility of some gram negative bacteria producing carbapenemases and extended spectrum $\beta$-Lactamases," International Journal of Microbiology and Immunology Research, vol. 2, no. 6, pp. 064-069, 2013.

[19] D. Rynga, M. Shariff, and M. Deb, "Phenotypic and molecular characterization of clinical isolates of Acinetobacter baumannii isolated from Delhi, India," Annals of Clinical Microbiology and Antimicrobials, vol. 14, p. 40, 2015.

[20] N. O. Eltai, A. A. A. Thani, K. Al-Ansari et al., "Molecular characterization of extended spectrum $\beta$-lactamases enterobacteriaceae causing lower urinary tract infection among pediatric population," Antimicrobial Resistance and Infection Control, vol. 7, p. 90, 2018.

[21] Y. Kuldeep and S. Nitika, "Detection of ESBL \& MBL producing E. coli from urine samples in a tertiary care hospital in Jaipur, Rajasthan," Scholars Journal of Applied Medical Sciences, vol. 5, no. 4A, pp. 1259-1272, 2017.

[22] A. S. Sikarwar and H. V. Batra, "Prevalence of antimicrobial drug resistance of Klebsiella pneumoniae in India," International Journal of Bioscience, Biochemistry and Bioinformatics, vol. 1, no. 3, pp. 211-215, 2011.

[23] A. Bitew, M. Tamirat, and C. Meseret, "Species distribution and antibiotic susceptibility profile of bacterial uropathogens among patients complaining urinary tract infections," BMC Infectious Diseases, vol. 17, no. 654, pp. 1-8, 2017.

[24] I. Ali, Z. Rafaque, S. Ahmed, S. Malik, and J. I. Dasti, "Prevalence of Multi-drug resistant uropathogenic Escherichia coli in Potohar region of Pakistan," Asian Pacific Journal of Tropical Biomedicine, vol. 6, no. 1, pp. 60-66, 2016.

[25] M. I. Ajah, I. R. Iroha, L. O. Ajah et al., "First report of uropathogenic isolates from ante-natal clinic attendees at Federal Teaching Hospital Abakaliki (fetha), expressing multidrug resistance traits," International Journal of Pharmaceutical Sciences and Health Care, vol. I6, no. 3, pp. 1-29, 2016.

[26] O. A. Olufunke, O. A. Aregbesola, and C. D. Fashina, "Extended spectrum beta- lactamase- producing uropathogenic Escherichia coli in pregnant women diagnosed with urinary tract infections in south-western Nigeria," Journal of Molecular Biology Research, vol. 4, no. 1, pp. 34-42, 2014. 
[27] R. P. Rapp, "Antimicrobial resistance and antibiogram evaluation: a new practitioner's preparation for antimicrobial stewardship," in Proceedings of the 2011 Midyear Clinical Meeting Presentation, American Society of Health-System Pharmacists, New Orleans, Louisiana, December 2011.

[28] J. Wang, R. Stephan, M. Karczmarczyk, Q. Yan, H. Hächler, and S. Fanning, "Molecular characterization of blaESBL-harboring conjugative plasmids identified in multidrug resistant Escherichiacoli isolated from food-producing animals and healthy humans," Frontiers in Microbiol, vol. 188, no. 2, pp. 1-9, 2013.

[29] T. Barua, M. Shariff, and S. S. Thukral, "Detection and characterization of AmpC B-lactamases in Indian clinical isolates of Escherichia coli, Klebsiella pneumoniae and Klebsiella oxytoca," Universal Journal of Microbiology Research, vol. 1, no. 2, pp. 15-21, 2013.

[30] K. Shigemura, M. Yamashita, K. Shigemura et al., "Chronological change of antibiotic use and antibiotic resistance in Escherichia coli causing urinary tract infections," Journal of Infection and Chemotherapy, vol. 17, no. 5, pp. 646-651, 2011.

[31] I. R. Iroha, C. O. Esimone, S. Neumann, L. Marlinghaus, M. Korte et al., "First description of Escherichia coli producing CTX-M-15- extended spectrum beta lactamase (ESBL) in outpatients from southeastern Nigeria," Annals of Clinical Microbiology and Antimicrobials, vol. 11, no. 19, pp. 1-5, 2012.

[32] K. Padmavathy, S. Rajasekaran, and K. Padma, "Extendedspectrum $\beta$-lactamase/AmpC-producing uropathogenic Escherichia coli from HIV patients: do they have a low virulence score?" Journal of Medical Microbiology, vol. 62, no. 3, pp. 345-351, 2013.

[33] I. Iroha, M. Adikwu, C. Esimone, I. Aibinu, and E. Amadi, "Extended band Beta Lactamase (EBSL) in E. coli isolated from a tertiary hospital in Enugu state, Nigeria," Pakistan Journal of Medical Sciences, vol. 25, pp. 279-282, 2009.

[34] E. Eskandari-Nasab, M. Moghadampour, and A. Tahmasebi, "Prevalence of blaCTX-M gene among extended-spectrum $\beta$-lactamases producing Klebsiella pneumoniae clinical isolates in Iran: a meta-analysis," Iranian Journal of Medical Sciences, vol. 43, no. 4, pp. 347-354, 2018.

[35] V. Krishnamurthy, G. S. Vijaykumar, M. Sudeepa Kumar, HV. Prashanth, R. Prakash, and E. R. Nagaraj, "Phenotypic and genotypic methods for detection of extended spectrum $\beta$ lactamase producing Escherichia coli and Klebsiella pneumoniae isolated from ventilator associated pneumonia," Journal of Clinical and Diagnostic Research, vol. 7, no. 9, pp. 1975-1978, 2013.

[36] A. Endimiani, A. M. Hujer, K. M. Hujer et al., "Evaluation of a commercial microarray system for detection of SHV-, TEM-, CTX-M-, and KPC-type -lactamase genes in gram-negative isolates," Journal of Clinical Microbiology, vol. 48, no. 7, pp. 2618-2622, 2010.

[37] L. L. Logan and R. A. Bonomo, "Metallo- $\beta$-lactamase (MBL)producing enterobacteriaceae in United States children," Open Forum Infectious Diseases, vol. 3, no. 2, pp. 1-4, 2016.

[38] C. Ejikeugwu, I. Iroha, C. O. Amaechi et al., "Multiple antibiotic resistance, antibiogram and phenotypic detection of metallo-beta-lactamase (MBL) from Escherichia coli of poultry origin," Journal of Applied Microbiology and Biochemistry, vol. 1, no. 4, pp. 1-5, 2017.

[39] C. Ejikeugwu, C. Esimone, I. Iroha et al., "Detection of metallo- $\beta$-lactamase (MBL) among carbapenem-resistant gram-negative bacteria from rectal swabs of cow and cloacae swabs of poultry birds," Annals of Medical and Health Science Research, vol. 7, pp. 51-56, 2017.
[40] A. Madhavan and V. Jayalakshmi, "Occurrence of extendedspectrum beta-lactamase, AmpC and MBLase producers among multidrug-resistant enterobacteriaceae causing urinary tract infection in a tertiary health-care teaching hospital," Journal of the Academy of Clinical Microbiologists, vol. 18, no. 2, pp. 80-85, 2016.

[41] C. Dallenne, A. Da Costa, D. Decré, C. Favier, and G. Arlet, "Development of a set of multiplex PCR assays for the detection of genes encoding important $\beta$-lactamases in Enterobacteriaceae," Journal of Antimicrobial Chemotherapy, vol. 65, no. 3, pp. 490-495, 2010.

[42] M. J. Ellington, J. Kistler, D. M. Livermore, and N. Woodford, "Multiplex PCR for rapid detection of genes encoding acquired metallo-lactamases," Journal of Antimicrobial Chemotherapy, vol. 59, pp. 321-322, 2007. 